\title{
Izobraževanje za sodelovanje: Urejanje prostora mora $v$ šolo!
}

\begin{abstract}
Prispevek izhaja iz teze, da je prostorsko načrtovanje odvisno od poznavanja potreb in značilnosti uporabnikov, in zato sta vključevanje uporabnikov $v$ načrtovalsko prakso in sprejemanje odločitev o razvoju v prostoru pričakovani razvojni fazi. Teza je podprta z opisom značilnosti prejšnje načrtovalske prakse $v$ razvitem svetu, primerjalni oris značilnosti prejšnje slovenske prakse pa je uporabljen za opis razmer, ki obvladujejo sodelovanje udeleženih v domači načrtovalski praksi. Sodelovanju kot načinu aktivnega vključevanja udeleženih $v$ zgodnje faze načrtovanja in sprejemanja odločitev besedilo pripisuje pozitivne učinke in ga opredeli kot način dela in življenja $v$ prihodnosti. Prispevek povezuje potrebe po znanju, ki jih čutijo prostorski načrtovalci, s pozivi k izobraževanju za trajnostni razvoj in predstavi nekatere pobude in možnosti za učenje o urejanju prostora $v$ šoli.
\end{abstract}

\begin{abstract}
The article emphasises the role of users in spatial planning and development and states that user involving techniques are elementary part of spatial planning methodological framework. By making a short overview trough the history of opening the spatial professions to the public in last decades the article points out two issues: the inevitable importance of substantial communication between professionals and users and the irrefutable underdevelopment on this field in Slovenia. Because of the several benefits that participation has on the spatial development, management and quality of life, all involved sides are interested for better understanding. Thereby everybody needs new knowledge and in the article this is related to the ideas of several international education initiatives related to the sustainable development and some activities that are going on at the time in Slovenia to incorporate spatial planning and related themes in school.
\end{abstract}

\author{
Izobraževanje \\ Prostorsko \\ načrtovanje \\ Sodelovanje \\ Urejanje prostora \\ Education \\ Public \\ participation \\ Spatial \\ management \\ Spatial planning
}

\section{Izhodišča}

Slovenski uporabniki vse bolj kritično spremljajo prostorsko prakso in kulturo. Za zdaj se ta kritičnost kaže kot bolj in manj uspešno postavljanje po robu posameznim posegom v prostor. V času, ki ne priznava ene same resnice, je poiskati drugo mnenje postalo norma. Dvom o pravilnosti odločitev in predlaganih rešitvah pa je znak razvitosti. Vloga arhitekta, urbanista, krajinskega arhitekta, ki radi verjamemo, da smo poklicani za kakovost rešitev v prostoru, postaja vse manj lagodna. Odločitve sprejemajo drugi, neredko tudi mimo strokovnih predlogov. Odgovornost za stanje v prostoru pa v očeh javnosti še vedno najpogosteje bremeni stroko. Prostorski načrtovalci imajo velikokrat občutek, da različni udeleženci v načrtovalskem procesu ne razumejo dobro njihovih predlogov, javnost ocenjuje, da ji stroka in politika nista pripravljeni prisluhniti, politika negoduje nad omejitvami, ki izhajajo iz prostorskega načrtovanja. Očitno je treba poskrbeti za boljše medsebojno razumevanje udeleženih $\mathrm{v}$ prostorskem načrtovanju.

Posledica velikih razlik v odnosu posameznikov in skupin do prostora so tudi problemi, ki so odsev nizke stopnje prostorske kulture, od malomarnega ravnanja s prostorom do razpršene gradnje, nekakovostne arhitekture, praznjenja mestnih jeder, odnosa do kulturne dediščine in urejanja javnega prostora. Stroka, uporabniki in politika danes pogosto gledamo na prostor iz različnih perspektiv. Vrednote prostora, ki so nam na deklarativni ravni skupne, na ravni vsakdanjega življenja doživljamo različno (Hočevar et al.,
2005). Te razlike vplivajo na iskanje rešitev, na vsakodnevno prakso $\mathrm{v}$ prostoru in presegajo možnosti posameznikov in strokovnih skupin. V resnici je stanje $\mathrm{v}$ prostoru zelo močno povezano prav $\mathrm{z}$ odnosom uporabnikov do prostora. Čeprav se zdi, da posamezne dežele premorejo več dobrih prostorskih ustvarjalcev kot druge, je možno razloge za razlike $\mathrm{v}$ ravnanju s prostorom iskati predvsem v tem, kaj zgledna okolja vodi po poti uspešne prakse. Višjo stopnjo prostorske kulture praviloma razbiramo v okoljih, ki so v minulih desetletjih izvajala dosledno prostorsko in arhitekturno politiko. Več uporabnikov z oblikovanim odnosom do kakovosti v urejanju prostora je posledica vztrajnega in razumljivega nagovarjanja javnosti, ki že vsaj zadnja štiri desetletja temelji tudi na vključujočem načrtovanju in odločanju. Družbeno nor- 
mirano ravnanje s prostorom je zato lahko v družbah, tradicionalno zavezanih kakovosti urejanja prostora, kot so na primer na Danskem, Švedskem ali Finskem, že močno prevzelo vlogo normativov in danes vpliva tudi na zaznavo prostorskih vrednot ter posredno na razvojne odločitve in ravnanje $\mathrm{s}$ prostorom $\mathrm{v}$ teh okoljih.

Povezanost urejanja prostora z vsakodnevno uporabniško prakso je tako tesna, da je sodelovanje z uporabniki verjetno treba razumeti kot sestavni del strokovnega razvoja, enakovreden teoretičnim, zgodovinskim in drugim gradnikom strokovnega znanja (Simoneti, 2004). Urejanje prostora se tudi po tradiciji odpira najširši javnosti. Po eni strani je odvisno od poznavanja uporabniških značilnosti in potreb, po drugi je upravljanje prostora vedno odvisno od naveze med organiziranimi sistemi in ravnanjem uporabnikov. V tem pogledu je vključujoče načrtovanje možno razumeti kot razvojno stopnjo, ki za potrebe optimiziranja rešitve in sprejemanja odločitev dejavno povezuje uporabnike, načrtovalce in odločevalce. Vključevanje uporabnikov v opredelitev prostorskih rešitev, od ideje do rešitve, izvedbe in vzdrževanja, je pomembno iz več razlogov. Sodelovanje na primer zagotavlja večjo stopnjo sprejemljivosti posega z vidika udeleženih in vpliva na stopnjo povezanosti s sprejeto odločitvijo, kar se v praksi izkaže kot odnos do rabe in vzdrževanja (Simoneti, 1997). Udeležene pri načrtovanju res lahko vodijo zelo različni vzgibi in poenostavljeno rečeno celo vsak išče nekaj zase, očitno pa se njihovi interesi pri sodelovanju srečajo vzajemno sprejemljivo in zato večina modernih priporočil za dobro prostorsko prakso izhaja iz vključevanja uporabnikov v procese od idejnih zasnov do izvedb, prenove in vzdrževanja.

Izobraževanje prostorskih načrtovalcev se tako danes razvija tudi v raziskovanju tehnik vključujočega načrtovanja in predvsem $v$ prouče- vanju načinov predstavljanja rezultatov svojega dela zainteresirani javnosti. Komunikacijske veščine, ki jih sodelovanje zahteva od prostorskega načrtovalca, daleč presegajo sposobnost grafičnega in pisnega opisovanja neke rešitve. Proces sodelovanja namreč zahteva sposobnost sprejemanja drugačnih pogledov in predlogov ter s tem povezano učinkovito vsebinsko odzivnost. V razmerah, ki od stroke zahtevajo sestop s položaja v problem posvečenega, je način komuniciranja stroke $\mathrm{z}$ uporabniki in zainteresirano javnostjo bolj kot kdaj odvisen od znanja. Znanja o prostorskem načrtovanju pa za uspešno sodelovanje $\mathrm{v}$ Sloveniji manjka tudi širši javnosti.

Odpiranje prostorskega načrtovanja širši javnosti lahko razložimo kot pričakovano razvojno stopnjo strokovnega dela, ki jo spremlja potreba po izobraževanju, prostorskih načrtovalcev in javnosti. $\mathrm{V}$ času, ko je tudi $\mathrm{v}$ mednarodni skupnosti prevladalo mnenje, da je naša prihodnost odvisna prav od znanja, in zato na pobudo Organizacije Združenih narodov sočasno poteka več svetovnih izobraževalnih programov, je naše razmišljanje še toliko bolj primerno (Links ..., 2005). Še posebno dobro je, da se je v sklopu Unesca lani začel program Desetletje izobraževanja za trajnostni razvoj (Decade of Education for Sustainable Development DESD), ki lahko postane dobrodošel okvir razvoju izobraževanja o urejanju prostora in vrednotah prostora $\mathrm{V}$ Sloveniji. Različne družbene skupine kritično ocenjujejo razmere v domači praksi in pozivi k zagotavljanju možnosti za boljše sporazumevanje, sodelovanje se vse večkrat dotaknejo potrebe po dodatnem izobraževanju. Prostorski načrtovalci gotovo prvi izražajo skrb za kakovost in iščejo zaveznike, zato je namera Ministrstva za okolje in prostor, da izda splošni informativni priročnik o urejanju prostora in zasnuje zbirko publikacij, ki bi nastale v sodelovanju še z drugimi zainteresiranimi sektorji, ter preraste $\mathrm{v}$ izobraževalni portal, razumljiva (Simoneti et al., 2005). Resnejši korak proti aktivnemu nagovarjanju izobraževalnega sistema pa je projekt R.A.V.E. Space (www.rave-space.org), ki pod vodstvom ministrstva poteka $\mathrm{v}$ sklopu programa INTERREG IIIB CADSES.

\section{Uporabniki in načrtovalska praksa}

To, kako se je v preteklosti prostorsko načrtovanje povezovalo z uporabniki, odkriva vrsto razlogov, ki vplivajo na to razmerje, in predvsem poveže razvojne značilnosti $z$ vzajemnimi potrebami po širjenju znanja. Po drugi strani pa je predvsem čas po drugi svetovni vojni še nekoliko samosvoje zaznamoval slovensko prostorsko prakso in tudi druge države članice vzhodnega bloka, kar v razmerah, ko vsi iščemo poti do novega znanja, vpliva na posebne potrebe po znanju.

Družbena delitev dela je z množico različnih poklicev, strokovnih služb in organizacij odtujila človeka od urejanja prostora in gradnje, kar se je $v$ zadnjem stoletju pogosto pokazalo tudi v rešitvah, ki so jih uporabniki zavračali. Čeprav načrtovalsko delo izhaja iz poznavanja potreb in značilnosti uporabnikov, labko delo za namišljenega uporabni$k a$ zanese načrtovalca daleč od resničnosti in zgreši cilj. Pasivne tehnike vključevanja uporabniških potreb, kot so opazovanje, anketne in druge sistematične raziskave, so urbanizmu in arbitekturi lastne tebnike dela in se kažejo tako $v$ različnih standardih in normativih kot $v$ rešitvah, naravnanih na problem.

Aktivne oblike vključevanja uporabnikov v načrtovalsko prakso pa so v razvitem svetu iz različnih razlogov zaživele predvsem po drugi svetovni vojni (Sewell in Coppock, 1977). 
Nasledniki funkcionalistov so po drugi vojni prakso načrtovanja še povezovali z nedoločenim uporabnikom in izhajali iz odnosa umetnine in opazovalca ter ustvarjali uporabnikom odtujene rešitve, ki so konec šestdesetih spodbudile intenzivno kritiško in posredno tudi ustvarjalno razpoloženje $\mathrm{v}$ prostorskem načrtovanju razvitega dela sveta (Halprin, 1969). Kot je slikovito zapisal Mumford $\mathrm{v}$ ponatisu svoje knjige The Urban Prospect kar dvanajst let po prvi izdaji, je stanje mest kljub dramatičnemu izbruhu različnih kritiških besedil o mestu in njegovi naravi napredovalo od slabega k še slabšemu. Po skoraj štirih desetletjih pisanja, še pravi Mumford, je edini rezultat ta, da se konec šestdesetih večina ljudi zaveda, da je stanje mest kritično (Mumford, 1968). V takih razmerah je bilo pričakovano $\mathrm{z}$ različnimi prijemi opozarjati na neživljenjskost načrtovalskih rešitev in si prizadevati, da se je strokovno znanje selilo med uporabnike (Aleksander, 1977, Crosby, 1973, Rowe/Koetter, 1978). Razlog za odpiranje urejanja prostora najširši javnosti so bile predvsem nerazumljene rešitve $\mathrm{v}$ prostoru, ki so jih uporabniki zavrnili in ki so med drugim zamajale tudi ugled tistih, ki so o njih odločali. Kot se kaže tudi danes, je prav odločanje o razvoju v prostoru tisto, čemur lahko pripišemo najpomembnejšo vlogo pri neposrednem povezovanju prostorskega načrtovanja $\mathrm{z}$ uporabniki.

Odločanje je v urejanju prostora povezano s prostorom kot javno dobrino in sredstvi, ki so nemalokrat ali vsaj posredno tudi javna. Izvedeni posegi, ki ne zaživijo $\mathrm{v}$ svoji funkciji, so zato tudi zelo očiten znak nesposobnosti sprejemanja pravilnih razvojnih odločitev. Čeprav bi strokovnjaki morda želeli drugače, je prav odzivnost tistih, ki imajo mandat za odločanje, ta, ki lahko ključno opredeli položaj stroke v posameznem okolju. Ker so odločevalci odvisni od uporabniške odzivnosti, je šele dovolj od- mevno nezadovoljstvo javnosti tudi očiten znak za potrebo po spremembah. V tem pogledu je našemu spominu najbližja izkušnja s področja varstva okolja. Za utrjevanje danes morda samoumevne razvojne vloge varstva okolja je bila odzivnost najširše javnosti skoraj gotovo kritična, če ne vsaj enako pomembna kot različna strokovna dognanja in ugotovitve. Šele ko so se strokovna spoznanja, prevedena v širši javnosti razumljiv jezik, pojavila v vsakodnevnih razpravah in skrbeh ter s tem povezanih zahtevah za spremembe, so postale okoljske vsebine politično »zanimive «. Politika in gospodarstvo se brez posredovanja javnosti nista odzivala na strokovna opozorila in posredovanja za spremembe v odnosu do okolja (Simoneti, 2004).

$V$ tem pogledu bi bilo dobro, da bi tudi stroke, delujoče pri urejanju prostora, razumele svoj posebni in hkrati omejeni položaj. $V$ našem okolju smo bili prikrajšani za posamezne izkušnje iz razvitega sveta, ker mehanizmi javne odzivnosti in pritiska $v$ preteklosti pač niso delovali. Večina urejanja prostora, delovanja in vzdrževanja javnih komunalnib sistemov se uporabnikov $v$ našem okolju v preteklosti ni dotikala. Prikrajšani za pomembno izkustvo soudeležbe pri sprejemanju odločitev in predvsem njibovih posledic danes uporabniki težko razumejo vse razsežnosti pomena in vloge urejanja prostora, predvsem pa ne vidijo svoje vloge $v$ njem.

Graditeljska dinamika je sredi sedemdesetih let prejšnjega stoletja $\mathrm{v}$ razvitem evropskem okolju ujela ritem potreb in pričakovanj tudi zaradi prizadevanj za prenos strokovnega znanja med uporabnike. Z razstavami in prvimi resnimi teoretičnimi priročniki so se začele razlike $\mathrm{v}$ pogledih na prostorsko prakso in posamezne rešitve srečevati v novih okoliščinah večjega ra- zumevanja (Crosby, 1973, Sewell in Coppock, 1977, Boalt, 1977). Razmere $\mathrm{v}$ tem obdobju so pozivale stroko k vključevanju uporabnikov $\mathrm{v}$ nove rešitve ter predvsem $\mathrm{k}$ strpnosti pri srečevanju z uporabniškimi pogledi na posamezne probleme. Odpiranje stroke je vplivalo na tehnike predstavljanja rešitev širši javnosti in spodbujalo uporabnike $\mathrm{k}$ izražanju svojih potreb in pričakovanj v zvezi z razvojem $v$ prostoru ter tudi $\mathrm{k}$ prevzemu odgovornosti za posamezne tako opredeljene odločitve. Skoraj štiri desetletja kasneje so se $\mathrm{v}$ teh okoljih razblinili že čisto vsi dvomi o tem, kam bo krenilo vključevanje javnosti, uporabnikov v urejanju prostora. Danes je participatorno načrtovanje, ki razume civilno družbo kot enega od partnerjev pri odločanju, splošno prevzeti model demokracije, ki se v praksi stalno in inovativno razvija. Naslovi, kot so Participatory Planning for Sustainable Communnities, People Oriented Cities, The Participatory City in podobni, razkrivajo najnovejša iskanja možnosti za povezavo stroke, uporabnikov, lastnikov in politike za uspešno urejanje prostora in upravljanje mest in naselij $\mathrm{z}$ vso kompleksnostjo njihovih funkcij.

\section{Značilnosti domače prakse}

Sredi sedemdesetih let je slovenska prostorska praksa še sledila dinamiki odpiranja urejanja prostora in povezovanja rešitev $\mathrm{z}$ uporabniki (Mlinar, 1973, 1978, Mestno stanovanjsko okolje, 1977). Razmere pa so vplivale na to, da so se pasivizirali tako uporabniki kot načrtovalci. Danes se zato v urejanju prostora srečujemo s predsodki in nezaupanjem, ki našo prostorsko stvarnost v več pogledih umeščajo daleč $\mathrm{v}$ preteklost kratko orisanih razmer v primerjalnih državah. Tako se stroka pri nas včasih še boji javnosti in jo nemalokrat celo podcenjuje, vsi razvojni programi, ki jim 
lahko sledimo v sklopu evropskega povezovanja (ESDP, 1999) ali posameznih nacionalnih primerov $(\mathrm{Na}-$ tional Spatial Strategy for Ireland, 2002-2020) ter strokovnih praks (ECTP, 2002), pa se v svoji izvedbeni vsebini opirajo prav na sodelovanje javnosti in vlogo, ki naj jo pri uveljavljanju posameznih politik, strategij in direktiv prevzemajo tudi uporabniki. Podobno ali še bolj to velja za različne izvedbeno naravnane razvojne programe, ki vodijo upravljanje prostora.

Čeprav minulo obdobje ni povsem izključilo domačih uporabnikov iz postopkov urejanja prostora, je bila ob začetku tranzicijskega desetletja večina izkušenj s sodelovanjem $\mathrm{v}$ procesih sprejemanja odločitev precej bledih in skromnih. Nov politični veter je spodbudil stroko in javnost. Praksa vključevanja javnosti v urejanje prostora je krenila proti sodelovanju in odpiranju stroke uporabnikom. Začetki avtocestnega projekta so tako pomembno povezani tudi z neformalnim vključevanjem javnosti v najzgodnejše načrtovalske faze (Kos, Simoneti, 2000). Nove razmere so $\mathrm{v}$ prostoru hitro razkrile novo stvarnost skromnih javnih sredstev in vse razsežnosti pomena novo ozaveščenega lastništva. Dober namen ni zadoščal glede na skromne izkušnje. Vodenje novega odprtega postopka v zanosu osamosvojitvene sproščenosti se je izkazalo za trdo delo. Mimogrede je populistično izkrivljanje strokovnih dejstev preprečilo izvedbo velikih posegov nacionalnega pomena ali prispevalo $\mathrm{k}$ porabi javnih sredstev za sporne rešitve. Kateri razlogi so krivi za stanje, v katerem je danes zaupanje med stroko in uporabniki daleč pod pričakovanim in potrebnim za sodelovanje, je razmeroma neraziskano (Kos, 2002). Še vedno je vsako opozarjanje na omejenost pravic, ki izhajajo iz lastnine v prostoru, skoraj neprimerno in še danes je pri nas redkost, če kdo opozori uporabnike na nujnost, da prevzamejo del odgovornosti za urejanje prostora. Oboje je v okolju
Evrope, za katero verjamemo, da spadamo vanj, samoumevno.

Nova prostorska zakonodaja je skladno s pragmatično prakso $\mathrm{v}$ zadnjih letih poslabšala razmere za kakovostno sodelovanje. Najodgovornejši je zakonodajalec, ki razen formalno predpisanih korakov vključevanja javnosti $\mathrm{v}$ postopke sprejemanja odločitev o posegih $\mathrm{v}$ prostor ni posebno spodbujal njenega aktivnega vključevanja ali si drugače prizadeval za odprtost razprave o razvoju v prostoru. Tako je v postopek sprejemanja odločitev vstopila logika tržnega komuniciranja, ki deluje na principu prepričevanja $v$ izbrano rešitev in je $v$ osnovi v nasprotju z vključujočim načrtovanjem. Kot najbolj problematično pa je verjetno treba oceniti nekakšno samoumevno sprejemanje dejstva, da večino sodelovanja pri nas še vedno izvajamo brez minimalnih osnovnih pogojev. Ne le da ne znamo voditi razprave in igrati vlog $\mathrm{v}$ novo pričakovanem »odprtem« urejanju prostora, v Sloveniji opozarjajo sociologi, temveč niti sistematično ne spremljamo razmer $\mathrm{v}$ urejanju prostora, kot nas ne bi zanimali stanje in odnosi med akterji v urejanju prostora (Kos, 2002). V resnici ne poznamo stališč različnih uporabniških skupin do večine žgočih prostorskih tem in $\mathrm{v}$ resnici je funkcionalna nepismenost Slovencev močno povezana tudi s sposobnostjo uporabe kart, grafov in podobnega gradiva, kar veliko ljudem onemogoča sicer priznano pravico do sodelovanja v urejanju prostora (Čelik, Simoneti, 2004).

Glede na stanje $v$ prostoru in razmere $v$ njegovem urejanju so načrtovalske stroke $v$ nezavidljivem položaju. Dogajanje v tranzicijskem desetletju je razgalilo omejeno moč strokovnih argumentov pri sprejemanju odločitev o posegih $v$ prostor. Nizka stopnja prostorske kulture, ki jo morda res zaznavajo predvsem občutljuvejši, ozaveščeni posamezniki, je v predstavah javnosti še vedno močno povezana s strokovnim delom. $V$ takih razmerah postaja stroka vec kot zainteresirana za to, da bi njene rešitve in stališča razumelo čim več uporabnikov, politikov, lastnikov zemljišč. Razmere, $v \mathrm{ka}$ terib stroka ocenjuje, da ji neodvisno, $z$ obstoječimi instrumenti urejanja prostora ne uspe prepričljivo voditi razvojne razprave, ji narekujejo, da svoje poglede predstavi uporabnikom in preveri njihovo upravičenost. Ugotovljeno zabteva prilagoditev strokovne produkcije na stopnjo uporabniškega razumevanja. Medtem ko strokouno pisanje, grafično gradivo in govorjena beseda iščejo javnosti razumljivejši izraz, se tudi čistijo in notranje razvijajo, kar je za stroko dobro. V iskanju poti do boljšega razumevanja se pojavljajo tudi prvi namigi, da je treba določeno prostorskonačrtovalsko znanje razširiti na kar najširšo populacijo.

Sodeč po poročanju medijev se tudi vedno več uporabnikov počuti izločene iz urejanja prostora in kritično ocenjuje posamezne politične odločitve, povezane s posegi v prostor. Kot že omenjeno, ljudje želijo vplivati na odločitve, ki so povezane $z$ njihovim bivalnim okoljem oziroma razmerami za njihovo življenje in delo, oziroma na tiste, ki se tičejo posameznih prepoznanih vrednot prostora. Interes javnosti je še posebno slišen $v$ zvezi $z$ velikimi posegi, ki vplivajo na javni prostor, naravne danosti ali izjemne kulturne prvine. Pogosto se izkaže, da bi se lahko interesi stroke in javnosti srečali, če bi se med sabo le sporazumeli in si zaupali.

Razlike, ki jih zaznavamo v odnosu do prostora in okolja, lahko pomembno ublaži samo izobraževanje. Stroke, ki delujejo v sklopu urejanja prostora, bodo gotovo vsaka zase, sčasoma pa tudi povezano delovale vedno bolj odprto in vključevale uporabnike $\mathrm{v}$ načrtovanje. Postopoma se bo podcenjevanje uporabnikov in pasivno vključeva- 
nje v načrtovalskoanalitične vsebine umaknilo razpravljanju o vsebinskih vidikih rešitev. Samo sestop stroke iz položaja v znanje posvečenih ne bo učinkovit, če ne bodo uporabniki opremljeni $\mathrm{z}$ novim znanjem. Stanje kliče po zasnovi celovite izobraževalne sheme, ki bo znanje, potrebno za sodelovanje $\mathrm{v}$ urejanju prostora, vključila $v$ redni izobraževalni sistem ter opredeljevala ciljne programe za dvig prostorske kulture in pripravo uporabnikov za aktivno in odgovorno vključevanje v sistem urejanja prostora. Tak progam je eden od prvih pogojev, da bomo laže nadoknadili zamujene lekcije iz demokratične prakse urejanja prostora (Simoneti, 2004).

\section{Moderno urejanje prostora se po- vezuje z zabtevnimi uporabniki in partnerskim načinom reševa- nja problemov ter predvsem $v$ po- vezavi z omejenostjo javnih sred- stev izhaja iz delitve odgovornosti med udeleženimi $v$ procese odlo- čanja. Za prevzem deleža odgo- dotaknila izobraževalnega procesa. Učitelji in generacije otrok so bili prikrajšani za najboljši možni izo- braževalni program s področja ure- janja prostora in še posebno arhitek- ture, za neposredno izkušnjo sodelo- vanja $\mathrm{v}$ procesu načrtovanja in gradnje svoje nove šole.} vornosti je treba javnost usposobiti. Urejanje prostora kot sistem, ki združuje tako formalnopravni okvir, strokovne službe in organizacije kot produktivno načrtovanje in oblikovanje, zato išče poti do najširše javnosti. V takih razmerab je mednarodna pobuda državam, naj pospešijo izobraževanje za trajnostni razvoj, samo še razlog več za zasnovo izobraževalne strategije, ki bo najširšo javnost opremila $s$ potrebnim znanjem o prostorskem načrtovanju, urejanju prostora in povezanih strokah.

\section{Urejanje prostora v šoli}

V času, ko je razmišljanje o trajnostnem razvoju dozorelo v spoznanje, da je naša prihodnost večinoma odvisna od ravnanja slehernega med nami, prihaja program izobraževanja za trajnostni razvoj pod Unes- com (DESD), ki je kot naročen tudi za vse, ki sodelujemo $v$ procesih urejanja prostora (UNECE, Strategy, 2005). Slovenske šole se že srečujejo $\mathrm{z}$ varstvom okolja in trajnostnim razvojem prek programov izobraževanja o okolju in programa Ekošola (www.ekosola.si). Urejanje prostora kot tisto, ki je okvir za usklajevanje vseh razvojnih odločitev in posegov v prostor, pa je za zdaj v splošnem izobraževanju še manj opazno. Celo znanje o arhitekturi in oblikovanju je danes $v$ teh izobraževalnih programih skromno. Pred dobrim desetletjem je spodletela akcija Arhitektura v šoli (Vahtar, 1995). Tako smo v tem obdobju v Sloveniji zgradili lepo število novih šol, katerih načrtovanje in gradnja pa se, v nasprotju s tujo prakso, praktično nista

Glede na razmere v urejanju prostora lahko pričakujemo, da bo program izobraževanja za trajnostni razvoj vključil med izobraževalne vsebine tudi vrednote prostora in ce.org). Kot ugotavljajo različni avtorji, je izobraževanje za trajnostni razvoj značilno povezovalno poučevanje, katerega cilj je opremiti udeležence $\mathrm{z}$ znanjem in predvsem izkušnjami, vedenjskimi vzorci in načini ravnanja, ki jim bodo v življenju pomagali sprejemati najboljše odločitve. Usodo odločitve za trajnostni razvoj večina avtorjev povezuje s sposobnostjo državljanov sveta, da bodo vsakodnevno sprejemali dobre odločitve, usklajene $\mathrm{z}$ razvojnimi viri in dogovorjenimi cilji širše skupnosti. Zato tudi nihče ne razmišlja o novih posebnih predmetih, ampak v večini držav iščejo možnosti v medpredmetnem povezovanju in navezovanju na zunanje vire znanja (Marentič Požarnik, 2005, Manual for School, 2004). urejanje prostora (www.rave-spa-
Urejanje prostora je zaradi vsebine in narave dela idealno področje za praktično proučevanje in vaje iz trajnostnega razvoja. Končno ves razvoj poteka bolj ali manj načrtovano in ima vplive na okolje. $\mathrm{V}$ urejanju prostora je še posebno prostorsko načrtovanje tisto, ki ima nalogo usklajevanja razvojnih interesov v prostoru, okolju in družbi, in tisto, ki povezuje različne stroke in uporabnike. Prostorsko načrtovanje je projektno naravnano in hkrati vedno tudi procesno vpeto v širše sisteme upravljanja. Razvojne odločitve $\mathrm{v}$ prostoru so že v izhodišču naravnane trajnostno. Prostorsko načrtovanje je zanimivo tudi zaradi javnega interesa, ki je v postopkih pravno zaščiten in daje vsakemu posamezniku pravico, da izrazi mnenje o kateremkoli razvojnem posegu. Demokratično sprejemanje odločitev o posegih v prostor je dobra priložnost za vaje iz državljanske vzgoje.

\section{Učenje o urejanju prostora}

Urejanje prostora lahko vstopa v izobraževalni program na več ravneh, skozi različne predmete in projekte. Iz povsem praktičnih razlogov je dobro ločiti učenje o urejanju prostora in urejanje prostora za učenje.

Učenje o urejanju prostora, še posebno o prostorskem načrtovanju, se osredotoča na značilnosti in vsebine urejanja prostora in se kar najbolj povezuje s poučevanjem geografije, hkrati pa se navezuje tudi na okolje, oblikovanje, zgodovino, lokalne skupnosti in demokratične prakse odločanja. V tem pogledu prostorsko načrtovanje povezuje socialno, ekonomsko in okoljsko področje.

Urejanje prostora ima hvaležno lastnost, da ponuja veliko različnih možnosti za učenje. Prav nobene potrebe namreč ni, da bi za bogato 
izkušnjo sedli na vlak ali avtobus. Razmerje med naravnimi danostmi in rabo prostora, ocenjevanje skladnosti med različnimi rabami in spoznavanje življenjskih navad so možni prav v vsakem kraju. Aktivno spoznavanje s procesi reševanja problemov $\mathrm{v}$ prostoru pa je sploh najučinkovitejše prav v domačem okolju. Delo v domačem kraju ima veliko prednosti, saj so časovni, podatkovni in človeški viri ter posredno tudi ekonomski bistveno manj omejeni kot pri izletih $\mathrm{v}$ druge kraje. Projektno delo je lahko bolj poglobljeno in rezultati imajo lahko neposreden učinek na razmere življenja in dela v kraju.

Prostorski načrtovalci vemo, da je velikokrat zelo pomembno že samo sodelovanje, ki se ponuja pri različnih projektih, povezanih z urejanjem prostora. Tudi brez otipljivih rezultatov $\mathrm{v}$ prostorskih rešitvah zato kot razvoj ocenjujemo že samo razpravo in odnose, ki se ob nekem posegu razvijejo med lokalno skupnostjo, investitorji, načrtovalci in odgovornimi za urejanje prostora. Podobno lahko v šoli gledamo na projekte, v katerih se otroci, učitelji in drugi sodelujoči povežejo in rešujejo neko nalogo. Četudi nas rezultati ne navdušijo, je dobro vedeti, da je sam spoznavni proces, ki spremlja delo pri nalogi iz vsakdanjega življenja, tisto znanje, ki ga bodo mladi v prihodnosti še kako potrebovali. Ne gre za podcenjevanje objektivnega znanja po posameznih predmetih, ampak za zavest o pomenu sposobnosti povezovanja različnega znanja, iskanja informacij, povezovanja $z$ drugimi ljudmi in iskanja novih rešitev, ki naj bi v negotovih časih prihodnosti vplivala na sposobnost posameznika za delo in življenje.

Prostorsko načrtovanje ponuja še dodatne priložnosti za učenje v sklopu urejanja prostora za učenje. V skladu s spodbujanjem selitve pouka iz učilnic na prosto je odprte veliko možnosti. Čeprav je ideja o selitvi pouka na prosto povezana prav $\mathrm{Z}$ vsemi predmeti in ni posebno nova, je danes zelo tesno navezana tudi na ideje o bolj zdravem načinu življenja in jo prav izobraževanje za trajnostni razvoj ultimativno zahteva (Landscapes for learning). Selitev poučevanja $\mathrm{V}$ realno okolje, najsi bo prirejeno za pouk ali ne, je za izobraževanje za trajnostni razvoj nujna.

Urejanje prostora za učenje je namenjeno ustvarjanju razmer za pouk na prostem. Po eni strani obstajajo možnosti, da se skoraj vsak predmet, vsaj občasno, lahko poučuje tudi na prostem, zato je zanimiva povezava kurikulumov s prostorskimi potenciali na čisto teoretični ravni (Maljevac, 2004). Po drugi strani pa imajo šole praviloma omejene prostorske možnosti za delo na prostem, še posebno če želimo ob šoli zagotoviti tudi vsaj minimalne razmere $z$ a igro in rekreacijo. Iz tega razloga je pot do posamezne rešitve lahko še posebno zahtevna načrtovalska naloga.

\section{Sklep}

Prostorski načrtovalci opažamo, da za dosego kakovostnih razmer bivanja potrebujemo zaveznike, ki bodo lahko dejavno sodelovali pri načrtovanju in urejanju prostora (Simoneti, 2004). Načrtovanje prostorskega razvoja vključuje tako odnos do narave, kulturne dediščine in obstoječih ureditev kot tudi zasnovo novih rešitev $\mathrm{v}$ prostoru. Sodelovanje pri načrtovanju, urejanju in vzdrževanju vključuje tako razvojne možnosti kot pravice in odgovornosti, ki spremljajo tako sodelovanje. Stanje v prostoru je posledica veliko posamičnih odločitev, ki morajo biti med sabo dobro usklajene, da prostor deluje, je lep, dobro vzdrževan in postane kakovostno bivalno okolje. Hkrati ko se načrtovalci učimo tehnik vključevanja uporabnikov v načrtovanje, čutimo potrebo po tem, da bi širili svoje znanje.
Pod vodstvom Ministrstva za okolje in prostor RS tako poteka projekt R.A.V.E. Space (www.rave-space.org), s katerim sodelujoči proučujemo možnosti za poučevanje o vrednotah prostora $\mathrm{v}$ osnovni in srednji šoli. Projekt je odziv na potrebe različnih udeležencev v urejanju prostora, ki v vsakdanjem življenju pogrešajo uporabno znanje za sodelovanje, odločanje in delovanje. Gre za čisto praktična vprašanja, ki so najtesneje povezana s tem, kako delujeta naša družba in okolje in kakšno vlogo v njiju prevzemamo kot posamezniki. Zadrege, ki jih čutimo prostorski načrtovalci, niso nič manjše kot tiste, ki se jih zavedajo uporabniki prostora ali investitorji, so samo drugačne.

Mag. Maja Simoneti, univ. dipl. inž. kraj. arh., LUZ, d. d., Ljubljanski urbanistični zavod, Ljubljana

E-pošta: maja.simoneti@luz.si

\section{Pojasnilo: \\ V projektu R.A.V.E. Space je avto- rica kot predstavnica partnerja LUZ, d. d., zadolžena za zasno- vo strategije za izobraževanje o vrednotah prostora, ki jih ožje povezujemo s prostorskim načr- tovanjem in urejanjem prostora nasploh.}

\section{Viri}

Alexander, C. (1977) A Pattern Language. Oxford University Press, New York.

Boalt, C. (1977) Zapisi o problemih v zvezi z raziskovalnimi strategijami - interdisciplinarni pristop in sodelovanje uporabnikov. V: Mestno stanovanjsko okolje. Zbornik mednarodnega seminarja, Urbanistični inštitut RS, Ljubljana, str.1-6.

Crosby, T. (1973) How to play environmental game. Penguin Special in associtation with Arts Council of Great Britain.

Čelik, Matevž, Simoneti, Maja (2004) Stanovanja in stanovalci. V: Nove perspektive stanovanjske gradnje, zbornik simpozija in razstave, Stanovanjski sklad RS, Ljubljana, str. $164-171$.

ECTP (2002) Try it this way. Sustainable development at local level. European Council of Town Planners, Bolzano.

ESDP (1999) European Commission, Potsdam. 
Halprin, L. (1969) Creative Processes in the Human Environment. Braziller, New York, Fifth edition 1981.

Hočevar, M., Kos, D., Makarovič, J., Trček, F., Štebe J., Uršič, M. (2004) Vrednote prostora in okolja. CRP Konkurenčnost Slovenije 2001-2006, Univerza v Ljubljani, Fakulteta za družbene vede, Center za prostorsko sociologijo, Ljubljana.

Kos, D. (2002) Praktična sociologija za načrtovalce in urejevalce prostora. Fakulteta za družbene vede, knjižna zbirka Teorija in praksa, Ljubljana.

Kos, D., Simoneti, M. (2002) Odprimo urejanje prostora: razvojne priložnosti odpiranja prostora civilni družbi. V: Krajinsko planiranje $v$ dobi globalizacije, zbornik konference, Biotehniška fakulteta, Oddelek za krajinsko arhitekturo, Ljubljana, str. 213-219.

Links between the Global Initiatives in Education. (2005) Education for Sustainable Development in Action, Technical paper no. 1-2005, UNESCO Education Sector

Maljevac, T. (2005) Urejanje odprtega prostora osnovnih šol glede na učne načrte devetletke. dd, Biotehniška fakulteta, Oddelek za krajinsko arhitekturo.

Marentič Požarnik, B. (2005) Okoljska vzgoja ali vzgoja za trajnostni razvoj. Okoljska vzgoja v šoli, št.1, letnik VIII.

Mestno stanovanjsko okolje. (1977) Zbornik mednarodnega seminarja o raziskovalnih in načrtovalskih strategijah, Urbanistični inštitut RS, Ljubljana.

Mlinar, Z. (1973) Sociologija lokalnih skupnosti. Univerza v Ljubljani, FDV, Ljubljana.

Mumford, L. (1968) Grad u historiji.

National Spatial Strategy for Ireland, 2002-2020.

Rowe, C., Koetter, F.(1977) Collage City. MIT Press, Cambridge, Massachusetts.

Sewell, W. R. D., Coppock, J. T. (1977) Public Participation in Planning. John Wiley and Sons, London.
Simoneti, M. (1997) Mestne zelene površine. Znanstveno publicistično središče, zbirka Spektra, Ljubljana.

Simoneti, M. (2004) Vključevanje javnosti v postopek izdelave prostorskih aktov. Priloga v : Drapal Pek, D., Drevenšek, M., Drapal, A. Odnosi z lokalnimi skupnostmi. Zbirka PR, Založba GV, Ljubljana,

Simoneti, M.(2004) Zavezništvo za dvig prostorske kulture. Krajinska arhitektura med danes in jutri: Zbornik 10. strokovne konference DKAS, Ljubljana, str. 21-27.

Simoneti, M., Zavodnik, A., Černe, A., Krajnc, U., Vidic, L., Demšar Miitrovič, P. (2005) ABC urejanja prostora. Splošni izobraževalni priročnik. Naročnik MOP UPR, Trajekt, Ljubljana.

UNECE strategy for education for sustainable development (2002) United Nations Economic and Social Council.

United Nations Decade of Education for Sustainable Development (DESD) 2005-2014. Vahtar, M. (1995) Izobraževanje o grajenem okolju doma in v svetu. Izdano ob tednu izobraževanja o grajenem okolju, UI RS, Ljubljana 1995.

www.ekosola.si

www.rave-space.org

\section{Literatura}

Education for Sustainable Development an upadate from DfES. (2005) Education and skills, SD Comission, UK, London.

Education for Sustainable Development. A Manual for Schools. The Royal Town Planning Institute, London, 2004.

Education Outside the Classroom Manifesto.

Hart, R. (1997) Childrens's Participation. Earthscan Publications, London.

URL: http://www.dfes.gov.uk/consultations/ conDetails. cfm?consultationld $=1370$

URL: http://www.odpm.gov.uk/stellent/ groups/odpm_planning/documents/page/ odpm_plan_023784.hcsp
URL: http://www.rtpi.org.uk/resources/consultations/envired/index.html

Spletna stran britanske svetovalne mreže na temo kakovost bivanja, arhitekture in gradnje z odličnim izobraževalnim podprogrmaom:

http://www.cabe-education.org.uk/

Spletna stran mednarodne akcije peš $v$ šolo: http://www.iwalktoschool.org/

Krajine učenja. (2005) strokovni posvet, zgibanka, Maribor, Osnovna šola Draga Kobala.

Making spaces, architecture and design for young children. Children in Europe, Issue 8, September 2005.

Mega, V. (1999) The Participatory City. Innovations in the European Union. Discussion Paper 32, Managment of Social Transformations - MOST

http://www.unesco.org/most/vmega.htm.

Participatory Planning for Sustainable Communities. International experience in mediation, negotiation and engagment in making plans, reserch report, The International Planning Unit of the Office of the Deputy Prime Minister of the UK.

Simoneti, M., Kranjc U., et al. (2005) Zasnova zbirke publikacij za promocijo urejanja prostora. Naročnik MOP UPR, LUZ, $d$. d., Ljubljana (gradivo za tisk).

Šuklje, E. I. (1999) Odprti prostori od šolah in domovih za stare. Raziskovalno poročilo, IU RS.

The Livable City. Revitalizing Urban Communities. (2000) Park, Paula editor, Mc Graw Hill Companies.

Tibbalds, F. (1992) Making People Friendly Towns. Longman Group UK Limited

United Nations Decade of Education for Sustainable Development 2005-2014. Draft international Implementation Scheme, UNESCO, 2005

www.cabe.org 